\title{
DUE PROCESS AND LEGISLATIVE STANDARDS IN SENTENCING
}

Sentencing is the most difficult and usually the sole function of the court on the criminal side of its docket. In the vast majority of cases the defendant pleads guilty, ${ }^{1}$ and the only problem is to determine his treatment. This disposition is of critical importance for both society and the defendant. A short sentence, an ill-advised probation or a fine may mean that society is inadequately protected. ${ }^{2}$ If a severe penalty is imposed, the bitterness and deterioration which often result from prolonged incarceration may irreparably damage an otherwise reformable offender.

If treatment is to be individualized, ${ }^{3}$ then the court's action in any given case requires predictions based on a wide variety of factors, many of them unrelated to the immediate criminal offense. The likelihood of recidivism must be weighed against probable personality disintegration of imprisonment and the social waste of maintaining at public expense a man who might otherwise be a selt-supporting and contributing economic unit. ${ }^{4}$ But the extent to which the difficult task of individualization should even be attempted is disputed. "Equality of treatment" has been called a "nearly universal principle applicable to criminal sentences." 5 If this means that two burglars guilty of similar offenses under similar circumstances should get approximately the same treatment, then it is in direct conflict with individualization, for by the latter theory the characteristics and needs of each offender may justify letting one off with probation while confining the other for life. Individualization also conflicts with other criminal law objectives, such as deterrence and retribution. Although the presentence report on an offender might urge probation because an excellent history justifies a prediction of no recidivism, a substantial prison sentence may still be imposed because the court believes that such action is necessary to deter others in similar situations or that the particular criminal act is one for

1. In 1950 , out of a total of 33,502 convictions in federal courts, 31,739 pled guilty or nolo contendere. REP. DIR. ADM. OFF. U.S. Crs. 178 (1950). See Chandler, Latter-Day Procedures in the Sentencing and Treatment of Offenders in the Federal Courts, 37 VA. L. REv. 825 (1951).

2. "Either too little time or too much time may prove disastrous to the purposes sought to be accomplished. - . . Frequently too much stress has been laid upon the injustice of long sentences. A sentence which is too short is equally harmful, both from the point of view of the offender and from the point of view of the public." Rep. Subcommittee on Sentencing Adult Offenders in REP. TO the Judictal CONF. of the Com. on Punisharent for Crme 25 (1942). 1911).

3. See Salemlles, The Individualization of Punishment (Jastrow Trans.

4. In the fiscal year 195114,554 federal offenders on probation reported earnings averaging $\$ 2,117.54$ per probationer. Had they been maintained in prison instead for the year, these earnings would have been lost, the cost of incarceration would have been $\$ 1,193.92$ per man, and many of their dependents would have had to have been supported on relief. Chandler, supra note 1 , at 839 .

5. Wyzanski, A Trial Judge's Freedom and Responsibility, 65 Harv. I. Rev. 1281,1292 (1952). 
which a "price" should be paid in punishment. This simultaneous pursuit of often mutually exclusive objectives has plagued both the practice and the reform of criminal sentencing.

These inherent difficulties and competing philosophies have not been resolved by legislation, which has simply delegated the problem to prosecutors, trial courts and administrative agencies such as parole boards. With the decrease of mandatory fixed sentences and the increasing use of widerange indeterminate sentences this delegation means a steady broadening of sentencing discretion. Parole or sentence fixing boards exercise a large slice of this power, for the majority of state court sentences are indeterminate ${ }^{6}$ and even where the sentence is determinate the effect is the same, because parole is usually available after a stated proportion of the sentence has been served. ${ }^{7}$ But the trial judge's discretion is still very broad. It is he who makes the choice between probation and imprisonment, and he still has an effective voice in the duration of imprisonment through his 'control over the base sentence which must be served before parole eligibility is reached.

It is not surprising that such discretion should give rise to great abuse. It was intended that disparity of sentence for the same offense would result from the wide range of dispositions made possible, for individualization requires differences in treatment. But the disparity has been so great, ${ }^{8}$ so apparently illogical, and so prejudicial to rehabilitation of offenders that demands for reform have been widespread. ${ }^{9}$ The most conscientious judge lacks guidance, since there are almost no legislative standards, appellate decisions on sentencing or explanatory opinions by trial court judges. ${ }^{10}$

6. See Prisoners in State and Federal Prisons and Reformatories for 1946, table 37 at 53 (Bur. Census 1948) (58.4\% of all prisoners serving indeterminate sentences).

7. E.g., 18 U.S.C. $\$ 714$ (1946) (prisoners may be released on parole after serving one-third of term).

8. "Variations between different district courts in handling convicted offenders is thus the rule, not the exception." WARNER \& CABOT, JUDGES AND LAW REFoRM 167 (1936). See Morse \& Beattie, Survey of tre Administration of Criminal JUSTICE IN OREGON 151 (1932).

9. ". . . there is serious need for reform in the present method of sentencing." REP., op. cit. supra note 2 , at 24 . ". . the question of how to improve the sentencing practices of judges is one of the vital problems in the field of law enforcement. . . The disparity in judicial sentences for similar types of offenders is one of the great unsolved problems of the relationship between courts and the correctional system." Ploscowe, The Court and the Correctional System in CoNTEMPORARY CORRECTION 51, 58-59 (Tappan ed. 1951).

10. ". . . while in murdel cases there is frequent reference to 'mitigating' or 'extenuating' circumstances, no tribunal, as far as I know, has ever attempted to express the reasoning which leads to a conclusion as to just what such circumstances consist of, or, generally, as to what factors in such cases should incline a jury or a court to imposition of the one penalty as against the other. The entire subject seems to be one of an uncharted sea, and, therefore, even the expression of an individual opinion may be a slight contribution toward some rationalized penology." Commonwealth v. Ritter, 13 Pa. D. \& C. 285 (1930). And see Ohio v. Edmonds, 29 J. Crim. L. \& Criminology 427 (Ohio C.P. 1938) (probation for manslaughter; "careful search for a discussion by the courts in this State or elsewhere of when probation is to be granted or denied has revealed none").

This means that there has been no development of any body of law explaining or rationalizing the sentences imposed; "the knowledge and wisdom of individual judges have thus died with them." WARNER \& CABOT, op. cit. supra note 8, at 160 . 
Judges, then, are left to their own "understanding of human nature," 11 with such guidance as they may have obtained from their knowledge of the practices of their colleagues, the recommendations of prosecuting attorney or defense counsel, and the reports of probation officers. Most judges come to sentencing without any special preparation, and neither law school nor the private civil practice from which they are frequently drawn is likely to have given them insight into the motivations and treatment of criminal behavior.

The judge who has his own theories of criminology can thus give them full play, and judges vary greatly in weighing the relative seriousness of different kinds of offenses. ${ }^{12}$ Those who have taken upon themselves the mission to "crusade against certain crimes which they feel disposed to stamp out by drastic sentences" commonly disregard the individual characteristics of the offender and impose sentences which are also out of line from a retributive or deterrent standard when "compared to less severe sentences for more serious crimes." 13 Such disparities are not confined to comparisons among different judges:

"From the data presented on the sentencing of convicted men by this one judge it becomes impossible to avoid the conclusion that the variations in sentences were not made on the basis of any insight into the individual problems involved in each case. Rather, it would seem that these men were sentenced according to the vacillations of the judge in response to the ever-changing popular feeling concerning crime." 14

A revealing illustration of disparity in sentencing is furnished by statistics on the use of probation in the federal courts. Under federal law,

11. Chandler, supra note 1 , at 846 .

12. E.g., average sentences imposed upon narcotic drug law violators in 1949 ranged from 7.6 months (Mass.) to 48 months (W.D. Ark.). FEDERAL Prisons 84-86 (U.S. Bur. Prisons 1949). In 1948 the Northern District of California gave 26 narcotics violators sentences averaging 41.5 months; the Southern District of the same state gave 35 violators sentences averaging 18.1 months. Frderal Prisons 81 (U.S. Bur. Prisons 1948).

Studying sentences imposed upon men sent to Sing Sing Prison over 20 years, "I found that while one judge would inflict an average minimum sentence of 5 years for larceny, first degree, in the same county another judge's sentences averaged only 1 year for the same crime and degree. One judge's minimum sentences for robbery, first degree, averages 26 years, 8 months, while another judge's averaged only 2 years for the same crime and degree. One judge's sentences for forgery averaged 5 years and for rape 1 year, while another judge's averaged 1 year for forgery and 5 years for rape." LAwES, LIFE AND DEATE IN SING Sing -10-11 (1937).

13. REP., op. cit. supra note 2 , at 27.

14. Morse \& Beatife, op. cit. sipra note 8 , at 164 . The judge described sentenced 15 men for robbery over a six months period; as newspaper publicity described a crime wave, the terms imposed rose steadily, the first man sentenced receiving 3 years and the last two 25 year terms. Individual characteristics apparently were not considered. The offender given 3 years had one prior conviction; one given 12 years had spent 24 out of the preceeding 30 years in prison; and one given 25 years was a first offender. Id. at 160-161. 
probation may be granted to any convicted offender (except for a few of the most serious crimes) whenever it shall appear to the satisfaction of the court "that the ends of justice and the best interest of the public as well as the defendant will be served thereby." 15 The percentage of offenders placed on probation varies so widely between districts $(4.0 \%$ in Western Texas, $66.7 \%$ in Rhode Island), between circuits (26.8\% in the Fifth Circuit, $57.9 \%$ in the Third Circuit) and between districts within each circuit ${ }^{16}$ that it is apparent that accidents of geography and individual judicial temperament, rather than the application of relevant criteria, usually control the employment of this treatment technique.

This widespread use of probation and the changing emphasis in treatment which it reflects have meant that new factors must be weighed by a sentencing judge in making dispositions. When the facts of the particular offense and the defendant's prior criminal record were all that most judges would consider, the problem of fact-finding was simplified. But "the modern probation report draws on information concerning every aspect of a defendant's life," 17 with the result that sentencing requires a judge to find and act upon facts which are unrelated to the particular criminal offense. These new practices and increased sentencing discretion create difficult new fact-finding problems in sentencing procedure. The failure to recognize this is a major source of confusion in the treatment of criminal offenders.

\section{Traditronal Scope of Sentencing Discretion}

A federal court has said: "If there is one rule in the federal criminal practice which is firmly established, it is that the appellate court has no control over a sentence which is within the limits allowed by a statute." 18 There are limited exceptions to this statement which will be discussed below: a few states provide by statute for judicial review of sentences, ${ }^{19}$ courts in a few jurisdictions have found such power, without explicit statutory authority, ${ }^{20}$ and there are some due process requirements of uncertain scope. ${ }^{21}$ But generally suitability of sentences and sentencing procedure are

15. 18 U.S.C. $\$ 3651$ (Supp. 1952).

16. Federal Prisons 98 (U.S. Bur. Prisons 1951).

17. Williams v. New York, 337 U.S. 241, 250 (1949). See The Pre-Sentence INVESTIGATION REPORT (Adm. Off. U.S. Cts. 1942).

18. Gurera v. United States, 40 F.2d 338, 340-341 (8th Cir. 1930). "Unless we are to over-rule sixty years of undeviating federal precedents, we must hold that an appellate court has no power to modify a sentence." United States $v$. Rosenberg, 195 F.2d 583, 604 (2d Cir. 1952). But cf. United States v. United Mine Workers, 330 U.S. 258, 304 (1947) ("excessive" fine reduced in contempt case where no statutory penalty).

19. E.g., ARIz. CODE ANN. c. 44, §2537 (1939); Iowa CoDe $\$ 793.18$ (1950). See L. Hall, Reduction of Criminal Sentences on Appeal, 37 CoL L. REv. 521 (1937).

20. See text at notes $44-46$ infra.

21. See text at note 49 et seq. infra. 
non-reviewable. ${ }^{22}$ Even where the appellate court is concerned because the sentence is "unduly severe" ${ }^{23}$ it still finds itself "powerless to intervene." ${ }^{24}$ Where the maximum for a single offense is exceeded through the device of imposing consecutive sentences for different counts in the indictment, if each of the several penalties were within the statutory limit the appellate court "is not concerned with the aggregate duration of the imprisonment." 25

The methods used in determining the sentence to be imposed are also generally held to be non-reviewable. The theory is that since a court has unrestricted power to impose the maximum penalty, it is irrelevant whether or not it "was influenced by circumstances which ought or ought not to enter into the consideration." 26 This applies even where the trial judge admittedly imposes a sentence because he feels that the defendant was guilty of something other than the offense for which he was on trial. In Peterson $v$. United States ${ }^{27}$ the defendant was convicted of the theft of a 40 cent

22. E.g., Scott v. State, 247 Ala. 62, 22 So.2d 529 (1945); State v. Horton, 132 Conn. 276, 43 A.2d 744 (1945); Sawyer v. State, 148 Fla. 542, 4 So.2d 713 (1942); State v. Snider, 111 Mont. 310, 111 P.2d 1047 (1941); State v. Sullivan, 241 Wis. 276, 5 N.W.2d 798 (1942).

The only limitations are that the sentence must be within the statutory maximum and that the defendant must be present when sentence is imposed. See Diaz $v$. United States, 223 U.S. 442 (1912) ; People v. Yurkiates, 404 I11. 157, 88 N.E.2d 458 (1949).

23. Blockburger v. United States, 284 U.S. 299, 305 (1932); accord, Beckett v. United States, 84 F.2d 731 (6th Cir. 1936).

24. Beckett v. United States, 84 F.2d 731, 732-733 (6th Cir. 1936). For finality of trial judge's discretion see also Cox v. State, 192 Md. 525, 64 A.2d 732 (1949) and cases cited.

Nor will a penalty be reviewed because it is alleged to violate the prohibition against cruel and unusual punishments. That restriction applies only to a direct attack upon the statute itself; if the penalty allowed by the statute is constitutional, no sentence imposed under it will be held cruel and unusual. E.g., United States v. Rosenberg, 195 F.2d 583, 607 (2d Cir. 1952); Gingerich v. State, 226 Ind. 678, 83 N.E.2d 47 (1948). But cf. State v. Brandon, 210 S.C. 495, 502, 43 S.E.2d 449, 452 (1947) (dissenting opinion): "I assume that the intent of the framers of our State Constitution in inserting the [cruel and unusual] clause ... was to bridle the judicial as well as the legislative branch of the government. . . ."

25. Scala v. United States, 54 F.2d 608, 611 (7th Cir. 1931) ; accord, Mitchell v. United States, 142 F.2d 480 (10th Cir.), cert. denied, 323 U.S. 747 (1944). Such sentences have been deplored: "We note that the defendant was sentenced to double the maximum punishment, through the device of treating the posting of two letters as separate crimes. We have often deprecated the practice; we do so again. But, as we have no power to intervene, we can go no further." United States v. Steinberg, 62 F.2d 77, 78 (2d Cir. 1932). And see Schwartz, Federal Criminal Jurisdiction and Prosecutors' Discretion, 13 LAw \& CoNTEMIP. ProB. 64, 79-80 (1948). Compare Code PENal Sursse ANN. $\$ 68$ (Panchaud ed. 1951) (where defendant sentenced for more than one offense, penalty limited to not more than half again as much as maximum for most serious single offense).

Two recent cases show how sentencing discretion is multiplied when a criminal transaction is broken up into "separate offenses" for each of which the maximum penalty can be imposed. See Oddo v. United States, 171 F.2d 854 (2d Cir. 1949) (cumulative punishment imposed for theft of goods belonging to different owners although contained in one vehicle); Aaronson v. United States, 175 F.2d 41 (4th Cir. 1949) (defendant who procured larceny and received stolen goods after they were stolen received consecutive sentences for both larceny and receiving stolen goods).

26. Bailey v. United States, 284 Fed. 126, 127 (7th Cir. 1922).

27. 246 Fed. 118 (4th Cir. 1917). 
stamp, for which the maximum penalty was imposed. The trial court stated that, although "the offense for which the defendant was formally found guilty" was "rather trifling," he believed that Peterson was also guilty of subornation of perjury, which was "the main reason for the severe sentence imposed." 28 This was held no abuse of discretion. In United States v. Sacher the court emphasised this rule, stating that a trial court's "reason for the length of the sentence would not affect its validity and should be ignored on appeal." 29 It follows that the court "is not bound by the strict rules of evidence applying in trials, since such a proceeding is not a trial in the ordinary sense of the word." 30 Therefore the judge can consider evidence on the commission of other crimes, ${ }^{31}$ "irrelevant and prejudicial hearsay testimony" 32 or statements of prosecutors "which there was no evidence to support." ${ }^{33}$ The presentence report may contain information gathered out of court and never submitted to the defendant, ${ }^{34}$ thereby depriving him of any opportunity to rebut possible errors. A few courts have said that "any information not received from the accused himself or not given in his presence, which might influence the judgment, should be called to his attention" to give him "a fair and full opportunity to answer charges made against him." 35 The Pennsylvania Supreme Court has suggested that such a practice, at least where the choices of penalty include death, is "the manifestly correct practice" and "might reasonably be held to be the required one." 36 But in the absence of a specific statute, apparently only South Carolina requires that all information bearing on sentence must be given in open court in the presence of the defendant. ${ }^{37}$

What has been said of the scope of the trial court's discretion is even more true of sentence-fixing administrative agencies. Release on parole

28. Ibid.

29. United States v. Sacher, 182 F.2d 416, 421 (2d Cir. 1950).

30. State v. Levice, 59 Ariz. 472, 478, 130 P.2d 53, 55 (1942); accord, People v. Williams, 14 Cal.2d 532, 95 P.2d 456 (1939); People v. Riley, 376 I11. 364, 33 N.E.2d 872, cert. denied, 313 U.S. 586 (1941); McCarty v. Hopkins, 61 Neb. 550, 85 N.W. 540 (1901) (plea of guilty waives all constitutional rights); Commonwealth ex rel. Hovis v. Ashe, $165 \mathrm{~Pa}$. Super. 30, 35, 67 A.2d 770, 772 (1949), aff'd, 364 Pa. 81, 70 A.2d 630, cert. denied, 339 U.S. 970 (1950).

31. People v. Popescue, 345 I11. 142, 177 N.E. 739 (1931) ; United States v. Dalhover, 96 F.2d 355 (7th Cir.), cert. denved, 305 U.S. 632 (1938).

32. Taylor v. United States, 179 F.2d 640 (9th Cir. 1950).

33. Stobble v. United States, 91 F.2d 69 (7th Cir. 1937).

34. Williams v. New York, 337 U.S. 241 (1949); Stephen v. United States, 133 F.2d 87, 100 (6th Cir.) cert. denied, 318 U.S. 78 (1943).

35. Zeff v. Stanford, 31 F. Supp. 736, 738 (N.D. Ga.), aff'd, 114 F.2d 1018 (5th Cir. 1940); accord, Stephen v. United States, supra note 34.

36. Commonwealth v. Johnson, $348 \mathrm{~Pa}$. 349, 354-355, 35 A.2d 312, 314 (1944).

37. State v. Simms, 131 S.C. 422,127 S.E. 840 (1925) (court said in sentencing that people had come to his office and spoken against defendant, sentence set aside); State v. Harvey, 128 S.C. 447, 454, 123 S.E. 201, 203 (1924) (offender being sentenced has right that all evidence "be open and above board and public"). But cf. State v. Reeder, 79 S.C. 139, 60 S.E. 434 (1908) (affidavits admitted).

Statutes in a few jurisdictions require that all such evidence be given in open court. See note 124 infra. 
is a matter of discretion and there is no review of the merits ${ }^{38}$ or of the procedure. ${ }^{39}$

This absence of a right to a substantial hearing on matters relevant to treatment produces an anomalous situation where there is a prior criminal record, which is universally regarded as an aggravating factor. Many states have enacted habitual offender laws which make possible "a stiffened penalty for the latest crime, which is considered to be an aggravated offense because a repetitive one." 40 If the penalty is to be increased under one of these laws, the defendant gets a hearing to make sure that the criminal record which is being used against him is actually his and is accurate. ${ }^{41}$ But if the same prior criminality is alleged in ordinary sentencing as the reason for imposing a severe sentence, the court may consider any sort of hearsay or rumor relative thereto without notice to the defendant, and thus deprive him of any opportunity to detect or correct error.

It has been suggested that this extreme reluctance of appellate courts to interfere with either sentencing procedure or the resulting disposition is in part "a desire not to engage in a most difficult undertaking," 42 and in part because of the view of some courts that appellate review conflicts with the executive pardoning power. ${ }^{43}$ Whatever the reason, the trial courts have a grant of unreviewabie discretion which in its far-reaching social and individual consequences is without parallel in the judicial system. It is incongruous that the protections afforded defendants against judicial abuse before they have been found guilty should disappear so completely after conviction, leaving them without safeguards in the assessment of penalty. Whether a convicted man gets probation or ten years in the penitentiary is not only the most crucial decision in his life but has important effects on the efficacy of the correctional system and the reduction of recidivism.

\section{Due Process as a Limit Upon Sentencing Discretion}

Against this background of sweeping discretionary power and dissatisfaction with the way in which that power has been exercised, there are signs of increased concern with the procedural aspects of sentencing. Some decisions in the last few years suggest the possible application to

38. Hines v. State Board of Parole, 293 N.Y. 254, 56 N.E.2d 572 (1944); In re Pierce v. Smith, 31 Wash. 2d 52, 195 P.2d 112 (1948).

39. United States ex rel. Foley v. Ragen, 143 F.2d 774 (7th Cir. 1944) ; O'Connor v. State Board of Parole, 58 N.Y.S.2d 726, 270 App. Div. 93 (3d Dep't 1945). But cf. People ex rel. Day v. Lewis, 376 I11. 509, 513, 34 N.E.2d 712, 713 (1941) (court might step in when no reasonable man could agree with board's exercise of discretion); State ex rel. Bush v. Whittier, 226 Minn. 356, 363, 32 N.W.2d 856, 860 (1948) (board urged to give substantial weight to mitigating factors).

40. Gryger v. Burke, 334 U.S. 728, 732 (1948). For a typical statute, see

Pa. Stat. Ann. tit. 18, \$5108 (Purdon 1945).

41. Ibid.

42. Judge Frank in United States v. Rosenberg, 195 F.2d 583, 607 n.29 (2d Cir. 1952).

43. See Walker v. State, 186 Md. 440, 444-445, 47 A.2d 47, 49 (1946). 
sentencing of minimum fair hearing requirements under the due process clause. These cases will be examined because, besides indicating an erosion of the doctrine of non-reviewability, they illuminate the defects which require correction by legislative action.

There have been scattered judicial exceptions to the general doctrine, but until recently none has rested upon due process. In a few jurisdictions appellate courts have construed their general appellate power to "reverse, affirm or modify" the judgments of the lower courts to permit reduction of sentences.44 In Pennsylvania such power has been used in a few death penalty cases, but it is exercised so rarely ${ }^{45}$ that it is of little practical importance except insofar as it has established some standards to guide trial courts in sentencing. ${ }^{46}$ A few courts have also reduced sentences because of "passion or prejudice." 47 There is probably more appellate review than appears on the surface, where courts reverse on what would otherwise be dismissed as harmless error because the record shows extreme severity or prejudice in sentencing. The Second Circuit has articulated this process in several cases, stating that "in weighing whether error is prejudicial, we have allowed an unusually harsh sentence to turn the balance." 48

The first intimation that due process would be used to strike at abuses in sentencing procedure was the 1948 decision of the Supreme Court in Tozensend v. Burke, ${ }^{49}$ reaffirmed in 1951 by Keenan v. Burke.50 These cases involved situations where the sentence imposed was within the statutory maximum, which would seem to make them non-reviewable. ${ }^{51}$ But the

44. Carson v. State, 206 Ark. 80, 173 S.W.2d 122 (1943); Idaho Code tit. 19, $\$ 2821$ (1948); State v. Miller, 65 Idaho 756, 154 P.2d 147 (1945). Much the widest use of this power is in Oklahoma; for a discussion of the Oklahoma cases see note 109 infra.

45. In Commonwealth v. Garramone, $307 \mathrm{~Pa} .507,514,161$ Atl. 733, 735 (1932), "the imposition of a sentence of death, instead of life imprisonment, was such abuse of discretion as to require modification by resentence. We are not commuting the sentence or otherwise performing the duty of the pardon board. "To reduce a sentence by amendment alters the terms of the judgment itself and is a judicial act as much as the imposition of the sentence in the first instance.' U.S. v. Benz, 282 U.S. 304, 311 [1931]." The only other Pennsylvania case is Commonwealth v. Irelan, 341 Pa. 43, 17 A.2d 897 (1941).

46. E.g., Commonwealth v. Caras, 53 Pa. D. \& C. 34, 45 (1945) ; Commonwealth v. Meholchick, $55 \mathrm{~Pa}$. D. \& C. 88, $89-90$ (1945). See von Moschzisker, Capital Punishnent in the Pennsylvania Courts, 20 PA. B. Ass'N Q. 174 (1949).

47. E.g., Montalto v. State, 51 Ohio App. 6, 199 N.E. 198 (1935) (record justifies conclusion that sentence was probably the result of prejudice rather than exercise of sound discretion; therefore sentence reduced).

48. United States v. Hoffman, 137 F.2d 416, 422 (2d Cir. 1943). See also United States v. Trypuc, 136 F.2d 901, 902 (2d Cir. 1943) : "Although no exception was taken to the charge as given and no error has been assigned, that does not preclude us from considering an unassigned error. . . . And the harshness of the four year sentence is justification for doing so in this case."

49. 334 U.S. 736 (1948).

50. 342 U.S. 881 (1951), a per curiam decision which cited Tozensend v. Burke without opinion.

51. Justice Minton, dissenting in Keenan v. Burke, 342 U.S. 881 (1951), stated the usual view: "It is utterly incomprehensible to me how a judge can commit a denial of federal due process by being facetious in the sentencing of defendants where the sentences he imposes are within the limits prescribed by statute." 
convictions were set aside for errors and abuse which, although relevant only to sentence and not to the issue of guilt or innocence, violated a due process "requirement of fair play." 52

The scope of this previously non-existent requirement is far from clear, and although very narrow interpretations have been suggested, ${ }^{53}$ the cases could also develop into a precedent of profound significance for sentencing procedure. The Tozmsend and Keenan cases involved between them four co-defendants who were sentenced on the same morning. The trial judge misread and made facetious remarks about the uncounselled defendants' criminal records before imposing severe prison sentences. The convictions were set aside because under such circumstances of misconduct and "careless or designed" error, absence of counsel prejudiced the defendants and was inconsistent with due process. ${ }^{54}$

This result has been regarded by some as simply another guidepost in the confused area where due process requires counsel in non-capital cases, ${ }^{55}$ and others have dismissed it as no more than an erroneous freak ban against being too facetious about the serious business of depriving a man of twenty years of his life. ${ }^{56}$ But neither of these analyses is particularly satisfactory, and the facetiousness interpretation is untenable on the record. At the sentence hearing each of the four defendants was questioned about the number of times he had "been here before," and the judge then proceeded to attack their credibility by reading from the criminal records which had been handed to him. His error consisted of including not only prior convictions but also arrests for offenses of which the defendants had been discharged or found not guilty. ${ }^{57}$ In the course of reading the records he made several attempts at humor, but as to only two of the four men could it be said that he was "facetious." 58 The Supreme Court opinion

52. Townsend v. Burke, 334 U.S. 736, 741 (1948).

53. See text at notes 55-56 infra.

54. Townsend v. Burke, 334 U.S. 736 (1948).

55. Note, 97 U. of PA. L. REv. 855 (1949).

56. See note 51 sitpra. The Pennsylvania Supreme Court has also so interpreted it. See note 58 infra.

57. Of the four defendants involved in the two cases, the trial judge made such errors in 2 of the 7 crimes he ascribed to Townsend, 2 out of 5 on both Keenan and Jankowski, 2 out of 3 on Foulke. Brief for Petitioners, pp. 4-6, Keenan v. Burke, 342 U.S. 881 (1951). If such record of mere arrests had been submitted to a jury in a Pennsylvania murder case to help them determine penalty, it would have been reversible error. Commonwealth v. Jones, $355 \mathrm{~Pa}$. 594, 50 A.2d 342 (1947). ments :

58. In reading from the criminal records the judge made the following state-

To Tounsend: "1937, received stolen goods, a saxophone. What did you want with a saxophone? Didn't hope to play in the prison band then, did you? Ten to twenty in the Penitentiary."

To Keenan: "Well, if you want to be gunmen you better get out of Philadelphia. This isn't a very happy hunting ground for you. Ten to twenty."

To Foulke: (with no humor) "I guess you are not as bad as the rest of them. Seven and a half to fifteen."

To Jankozeski: "1936, I don't know what-larceny of candy from Schulte's Cigar Store, Broad \& Arch. Do you like candy? . . . I don't think you are as 
in Tozensend emphasizes that the fact that the judge made an error was not the ground of the reversal, and the facetiousness is mentioned only as "cast[ing] a somewhat somber reflection on the fairness of the proceeding." " 59 It was rather that the record as a whole indicated that the errors "savor [ed] of foul play or of carelessness" and of an absence of "fair play," as distinguished from the kind of error which can result despite a "scrupulous and diligent search for truth." 60

Such cumulative misconduct is an important element in the determination of whether in a given situation there is a duty to provide counsel, for there is still adherence to the early English view that judges "are to be of counsel for the prisoners" 11 and "to see impartial justice done." 62 The judge must "conscientiously [undertake] the functions ordinarily entrusted to counsel" 63 and due process steps in where "neither counsel nor adequate judicial guidance or protection was furnished." 64

But this alternative view that the Torensend case simply applies deprivation of counsel doctrine to sentencing implies that counsel can correct the abuse, which here is a sentence "predicated on misinformation." Yet this is true only if the case is also regarded as requiring some elements of fair hearing in sentencing procedure. While presence of counsel would doubtless be calculated to improve judicial demeanor in sentencing, ${ }^{65}$ it is difficult to see how the right to counsel would be of substantial benefit unless it were coupled with the right to a fair hearing. Suppose in Tozensend and Keenan that the judge had merely read the criminal records to himself instead of aloud, but still with the same inclusion of arrests which had not re-

tough as the other two. Seven and a half to fifteen." Transcript of Record, pp. 8-9, Keenan v. Burke, 342 U.S. 881 (1951).

The Pennsylvania Supreme Court, in an unpublished per curiam opinion filed after the Supreme Court granted certiorari in the Keenan case, said that the "hunting ground" statement to Keenan, "while unnecessary, can hardly be classed as more than an exhibition of overzealous local civic pride and not so facetious as to vitiate the proceedings." It did not find the remarks to Keenan, Foulke and Jankowski "within the purview of Tounsend v. Burke." Commonwealth ext rel. Keenan v. Burke, filed June 27, 1951, in Transcript of Record, p. 77, Keenan v. Burke, supra (emphasis added). This would appear to be correct if facetiousness was the sole ground of Tozensend v. Burke.

59. Townsend v. Burke, 334 U.S. 736, 740, 741 (1948).

60. Id. at 741. Regarding this distinction, the Supreme Court on the same day failed to reverse in Gryger v. Burke, 334 U.S. 728 (1948), where the judge's error was his misreading of a statute to make mandatory what was in fact a discretionary life sentence. Four dissenting justices thought the decisions were irreconcilable; but if Tozenusend v. Burke was upset because the record as a whole showed that error resulted from unfairness in the proceedings, then the cases are distinguishable because no such unfairness was alleged in the Gryger case.

61. 4 BL. Coms. *324.

62. Betts v. Brady, 316 U.S. 455, 472 (1942).

63. Uveges v. Pennsylvania, 335 U.S. 437, 442 (1948).

64. Gibbs v. Burke, 337 U.S. 773, 781 (1949).

65. Of the six co-defendants in the original proceedings involved in the Tozemsend and Keenan cases, the only one who was represented by counsel received a markedly lower sentence than the uncounselled defendants, and in proceedings without humor or error. Transcript of Record, pp. 9-10, Keenan v. Burke, 342 U.S. 881 (1951). 
sulted in conviction. ${ }^{68}$ The defendant, with or without counsel, would then have been powerless to correct the error because he would not know that it existed, and by the usual view he would have no way of discovering it. It is difficult to believe that the Supreme Court meant to erect a "requirement of fair play" which would operate only when a trial judge created the occasion for rebuttal by chance revelation of the false premises upon which he was going to base his dispositions. By such a standard, the more taciturn the judge, the less chance of reversible error; but by such silence the likelihood of actual mistake or abuse would be increased.

The services of counsel in a criminal proceeding are merely a means to an end, and the duty to provide counsel in certain cases is thus "but one aspect of the comprehending guaranty of the Due Process Clause of a fair hearing on an accusation, including adequate opportunity to meet it." 67 Counsel must be provided where, for want of such services, "an ingredient of unfairness actively operated in the process that resulted in . . . confinement;" ${ }^{88}$ or where, even without actual prejudice, special circumstances created a situation "so apt to result in injustice as to be fundamentally unfair." 69 The requirements are to insure that the defendant "enjoy that fair notice and adequate hearing which constitute the foundation of due process of law in the trial of any criminal charge." 70 In sentencing, as in the trial, there can be such a substantial hearing only if there is notice of the accusation, ${ }^{71}$ which in sentencing includes aggravating treatment factors under consideration by the judge. The emphasis on "fairness" and the tenor of the Tozensend opinion imply such a hearing, and these are incompatible with restriction of the case to the forlorn gesture of requiring counsel without provision for the due process fundementals that would give counsel an effective role. However, the lack of a specific holding repudiating the weight of authority to the contrary leaves the issue unresolved.

A recent Pennsylvania case has applied the Torensend rule where the defendant was represented by counsel at sentencing but both were unaware of the contents of a presentence report before the trial court. In a petition for habeas corpus, the court held that defendant was entitled to a full hearing upon alleged misinformation in that report, and "if unknown to this prisoner or his counsel he was sentenced on assumptions concerning his past criminal activity which were untrue or upon misinformation as to other material facts," then the conviction would be set aside. ${ }^{71 a}$ As in the Torem-

66. It is difficult to believe that the error was not deliberate. The judge was reading from criminal record cards upon which the disposition of each charge was clearly marked. Reply Brief for Respondent, pp. 11-12, Keenan v. Burke, 342 U.S. 881 (1951).

67. Quicksall v. Michigan, 339 U.S. 660,661 (1950).

68. Foster v. Illinois, 332 U.S. 134, 137 (1947).

69. Uveges v. Pennsylvania, 335 U.S. 437,441 (1948).

70. Bute v. Illinois, 333 U.S. 640, 677 (1948).

71. ". . . real notice of the true nature of the charge against him [is] the first and most universally recognized requirement of due process." Smith v. O'Grady, 312 U.S. 329, 334 (1941).

71a. Ex parte Hoopsick, 91 A.2d 241 (Pa. Super. 1952). 
send case, the alleged misinformation was revealed accidentally, here in a letter written to the defendant after sentence had been imposed. ${ }^{\mathbf{7 1 b}}$ The fact that a full hearing on sentencing information will be required on habeas corpus proceedings, where alleged misinformation of which defendant had no notice is later revealed by chance, emphasises the lack of logic of the Tozensend rule unless it implies a hearing at the time of sentence.

The rationale that Tozensend imports due process hearing requirements into sentencing procedure fits in with recent allusions of the Court to the important function of counsel in the sentencing process, including the implication in one case that necessity of counsel sometimes may be greater at sentence than in the earlier stages of criminal procedure. ${ }^{72}$ It also parallels the recent imposition of due process hearing requirements in situations where, with the degree of murder not in dispute, a jury is to determine whether to inflict the death penalty or life imprisonment. In both Commonrealth v. Chambers ${ }^{73}$ and United States ex rel. Almeida v. Baldi ${ }^{74}$ convictions were upset for misconduct relevant only to the punishment imposed. In the Almeida case the prosecutor withheld evidence tending to show that the victim was killed by another police officer rather than, as the prosecution had contended, by the defendant. Under the Pennsylvania felony murder rule it was conceded that the crime was first degree murder no matter who fired the fatal shot, but the Court of Appeals nonetheless held the suppression to be denial of due process because it was "pertinent as to the issue of penalty." 75 In the Chambers case, error and/or misconduct of the trial judge took from the jury the controverted issue of an alibi ; as in Almeida, this did not affect the degree of guilt and was relevant only to show who did the actual killing in the course of a felony murder. The Pennsylvania Supreme Court reversed on the contention that without the error "the sentence might have been life imprisonment instead of death." 78 If these errors had affected guilt or innocence the results would have been routine. ${ }^{77}$ These cases are significant because they apply to the sentencing process rules which are usually applied only to that stage of the trial which comes before conviction. ${ }^{78}$

71b. The letter said in part: "There is no doubt that in the Borough of Osceola Mills you were considered as influencing a group of younger boys to commit the crime. Our pre-sentence investigation indicating from several people in Osceola that that was the reputation you had before these crimes were committed." Id. at 243 .

72. See Carter v. Illinois, 329 U.S. 173, 178 (1946). See also von Moltke v. Gillies, 332 U.S. 708, 721 (1948).

73. 367 Pa. 159, 79 A.2d 201 (1951).

74. 195 F.2d 815 (3d Cir. 1952), petition for cert. filed, 21 U.S.L. WEEK 3071 (U.S. Aug. 9, 1952).

75. $I d ., 195$ F.2d at 819,820 .

76. Commonwealth v. Chambers, 367 Pa. 159, 163, 79 A.2d 201, 203 (1951).

77. The Almeida case would have been reversed on the authority of Mooney v. Holohan, 294 U.S. 103 (1935) (suppression of evidence or use of perjured testimony to obtain conviction); and cf. Commonwealth v. Karamarkovic, $218 \mathrm{~Pa}$. 405, 408, 67 Atl. 650,651 (1907). The Chambers case would have been governed by the rule that questions of fact are for the jury.

78. See text at note 30 supra. 
It may be that the gist of these two cases is that a jury rather than a judge determines the penalty. ${ }^{79}$ But such a distinction would produce anomalous results. By this view, if a murder defendant pleads not guilty and a jury hears his case, he will be entitled to the elements of fair hearing as to factors relevant only to penalty; but if he pleads guilty and judges determine the penalty he will have no such rights in the consideration of those same factors. ${ }^{80}$ Yet in both types of procedure there is the same need to avoid errors due to inadequate notice and lack of opportunity for rebuttal.

The Townsend due process theory has been applied where an uncounselled defendant pleads guilty in reliance on a promise of a light sentence. ${ }^{81}$ Here there is the added factor, not present in the cases discussed heretofore, that the plea of guilty under such circumstances may not be a reliable indicator of actual guilt. ${ }^{82}$ This is especially true where the defendant also alleges that he was tricked and thought he was pleading guilty to a less serious charge. ${ }^{83}$ Therefore in these cases it has been the failure to provide counsel throughout the entire proceeding which has violated due process; but at least where there has been no deception in pleading it is the sentencing itself which is apparently regarded as the major abuse. Probably the most important reason for requiring counsel was the same as in the Tozensend case: to meet the "requirement of fair play" in sentencing procedure.

79. The fact that sentencing evidence must be gotten to the jury in open court answers the notice problem which exists when a judge determines the sentence and may receive ex parte information. For an earlier Pennsylvania dictum that a jury is "entitled" to be informed of all relevant penalty considerations in murder cases see Commonwealth v. Wooding, 355 Pa. 555, 559, 50 A.2d 328, 329 (1947). And compare practice under an Illinois statute providing for a hearing on sentences to be determined by a jury in murder cases, ILI. REv. STAT. c. 38, \$732 (1939), the court has said it would hold prosecutors to high ethical standards to offer no evidence of doubtful competency and materiality. See People v. Riley, 376 III. 364, 367, 33 N.E.2d 872, 874 (1941), cert. denied, 313 U.S. 586 (1941).

80. Where the trial court has been reversed for procedural errors after a plea of guilty, it has been for abuse in the hearing as to the degree of guilt and the sentencing hearing has been distinguished, although with the statement that the same strict rules "might reasonably" be required. Commonwealth v. Johnson, 348 Pa. 349, 35 A.2d 312 (1944). Cf. Commonwealth v. Petrillo, $340 \mathrm{~Pa} .33,47,16$ A.2d 50, 58 (1940). But see Commonwealth v. Sterling, $314 \mathrm{~Pa} .76,80,170$ Atl. 258, 260 (1934) (would be abuse of discretion if court "overlooked pertinent facts or has disregarded the force of the evidence or erred in its law").

81. Curtis v. Humphrey, 84 F. Supp. 969 (M.D. Pa. 1949). Here a 19 year old first offender was being brought back for trial by a U.S. marshal who advised him to plead guilty, said he would get him a light sentence. The defendant waived counsel, pleaded guilty, and got the maximum of 25 years. It was held, after two earlier decisions the other way had been reversed by the Court of Appeals, that on the authority of Toumsend, defendant's lack of counsel resulted in his being taken advantage of and violated due process. See Ex parte Sabongy, 18 N.J. Super. 334, 87 A.2d 59 (1952) (unconstitutional deprivation of counsel when defendant pleaded guilty and his counsel did not appear because prosecutor had assured both that judge would merely impose sentence to run concurrently with another sentence defendant was then serving, but judge imposed consecutive sentence); Commonwealth v. Claudy, $170 \mathrm{~Pa}$. Super. 488, 87 A.2d 492 (1952).

82. Compare the rule that a confession induced by a promise of milder punishment is inadmissible in evidence. 3 WIGMORE, EVIDENCE $\$ 835$ (3d ed. 1940). (1951).

83. Smith v. O'Grady, 312 U.S. 329 (1941) ; Palmer v. Ashe, 342 U.S. 134 
This analysis would indicate that counsel is required at sentencing to assure "fair play," that "fair play" means some sort of hearing, and that a hearing is little more than sham unless it embraces the right to know and thus be able to challenge adverse information. But not only does the traditional doctrine oppose such a logical implementation of the counsel requirement, but the right to adequate notice is denied in federal courts under rules formulated by the Supreme Court a few years before the Townsend decision. The proposed draft of the Rules of Criminal Procedure contained a provision which would have made presentence investigation reports available to defendants, but this was struck out by the Court, ${ }^{84}$ and today this information is withheld at the option of the trial court. ${ }^{85}$ This problem of the presentence investigative report was before the Court in 1949 in Williams $v$. New York, ${ }^{86}$ which sustained its admission over the contention that it was hearsay. Williams had been convicted of first degree felony murder with a jury recommendation of life imprisonment, but because of the damaging allegations in the probation report the judge imposed the death sentence. The Supreme Court opinion emphasized the desirability of flexible individualized sentencing, as opposed to "freezing the evidential procedure of sentencing in the mould of trial procedure." ${ }^{87}$ But the record reveals that what the Court called a "hearing" when sentence was imposed gave the defendant and his counsel almost no opportunity to see that the sentence was not "predicated upon misinformation." Counsel had not seen the probation report, were apparently unaware of its devastating contents, and made a routine appeal that the jury's recommendation be followed. The court then imposed sentence, prefacing it with a long statement which for the first time made public the allegations of prior criminality (of which there was no formal criminal record) and moral depravity contained in the report. Thus a procedure which lacks "the first requirement" of adequate notice was here regarded as a sufficient hearing for so grave a determination as the choice between life and death. But the Williams case does not foreclose this question, for the Court's holding goes only to the admissibility of the report, ${ }^{88}$ and the opinion stressed the fact that the defendant had not challenged it or asked to rebut its contents. ${ }^{89}$ The Court also noted that it was not disapproving Tozensend, ${ }^{90}$ but nonetheless

84. Second Preliminary Draft, Advisory Committee on Rules of Criminal Procedure Appornted BY U.S. Sup. CT. 127, Rule 34(c) (2) (1944). This became Rule 32(c) (2), with the last sentence of the draft eliminated. See Hincks, In Opposition to Rule 34(c)(2), Proposed Federal Rules of Criminal Procedure, 8 FED. Probation, Oct.-Dec. 1944 , p. 3.

85. "The practice varies between making the reports public in some districts and treating them as confidential for the information of the court to be used in its discretion in others." Chandler, supra note 1, at 834.

86. 337 U.S. 241 (1949).

87. Id. at 251 .

88. "We cannot say that the due process clause renders a sentence void merely because a judge gets additional out of court information to assist him in the exercise of this awesome power of imposing the death sentence." Id. at 252.

89. Id. at 244 .

90. "What we have said is not to be accepted as a holding that the sentencing procedure is immune from scrutiny under the due process clause. See Townsend $\mathrm{v}$. Burke, 334 U.S. 736." Id. at 252 n. 18. 
the opinion indicates a reluctance to interpret Tozensend along the broader lines suggested above. The resolution of the anomaly of requiring counsel for a proceeding where lack of notice may leave counsel helpless must wait for a case where, on facts like those in Williams $v$. Nere York, it is alleged that the probation report was prejudicially inaccurate and that there was no notice of it or opportunity for rebuttal.

To a less extreme degree the due process problem in sentencing parallels that raised in Skinner v. Oklahoma, which invalidated a statute providing for sterilization of certain habitual offenders. Chief Justice Stone in a concurring opinion found the major vice of the measure in its provision for sterilization of an offender "without giving him a hearing and opportunity to challenge the existence as to him of the only facts which could justify so drastic a measure." 92 In sentencing, the wide range of treatment possibilities which can be imposed on persons convicted of identical criminal offenses shows a legislative intent that factors other than the immediate offenses are to distinguish those who receive lenient treatment from those sent to the penitentiary for the maximum term. Thus the legislature has believed that only some members of the class of those who commit a given offense would merit so harsh a condemnation as the maximum sentence. Traditional sentencing doctrine, however, gives judges unbridled license to impose that sanction, which in major crimes is hardly less drastic than sterilization, on any member of the class without hearing, whenever judicial judgment or whim so dictates. Our concept of ordered liberty makes long overdue a due process requirement that the offender receive "a hearing and opportunity to challenge the existence as to him" of relevant treatment factors.

\section{LegisLative ReMEdies fOR NoN-Reviewability}

To the extent that due process requires a hearing on factors to be considered in sentencing, it would reduce the likelihood that unintentional error would influence the court's determination. Such a hearing would bring the sentencing function more into the open and would sharpen the focus upon the inequality and abuse of discretion that now exist. But this alone is not enough to achieve reasonable fairness in these important dispositions and to promote more effective use of varied treatment devices. This study of sentencing procedure suggests areas which are overripe for legislative consideration. Three will be noted here: legislative declaration of treatment policies and standards; implementation of due process requirements by provision for adequate hearing; and authorization for appellate review.

(1) Legislative Standards.-We have already noted that absence of legislative guidance and the concomitant failure to resolve basic conflicts of policy have left judges to find their own standards, which has resulted

91. 316 U.S. 535 (1942).

92. Id., concurring opinion at 544 (emphasis added). The majority invalidated the statute under the equal protection clause and did not reach the due process point. 
in sentencing discrepancies most vividly illustrated by the disparities in the use of probation..$^{93}$ This failure to provide standards by statute is directly related to the absence of both adequate hearing and appellate review. It leaves uncertain the factors upon which such a hearing should focus, and furnishes no measure by which a judge's action can be guided, challenged or reviewed. ${ }^{94}$ Even where appellate review exists, the court is left with a choice of imposing its own standards ${ }^{95}$ or of inferring those which it thinks the legislature must have had in mind. ${ }^{98}$

Nevertheless detailed legislative rules of individualization have generally been rejected in this country. . They have been called a "clumsy device," ${ }^{97}$ and it is said that because of peculiar individual variables, "no such absolute standards exist in precisely expressible form." 88 If the standards were to embrace "the myriad of variations that arise," then the categories would have to be "so general as to defeat their purpose." 99 Statutes concerned with treatment reflect this view. In Arizona, one of the few jurisdictions where the appellate courts have explicit power to reduce sentences, the only legislative guidance is that the power should be exercised where "the punishment imposed is greater than under the circumstances of the case ought to be inflicted." 100 In those jurisdictions with legislation which provides for a sentencing hearing on aggravating and mitigating circumstances, the statutes usually give no indication of what factors are to be considered as relevant. ${ }^{101}$ The only standard in most probation statutes is that of serving "the ends of justice and the best interest of the public as well as the defendant." 102 In general, then, treat-

93. See text at notes 15-16 sitpra.

94. See Gurera v. United States, 40 F.2d 338, 341 (8th Cir. 1930), stating that if there is to be judicial review the court would expect from Congress "a workable expression of the rules which should guide" the courts.

95. For the standards evolved by the Oklahoma Court of Criminal Appeals, see note 109 infra.

96. For an example of a court struggling to find legislative intent where no standards are provided see Commonwealth v. Garramone, $307 \mathrm{~Pa} .507,161$ At1. 733 (1932). (1928).

97. Glueck, Principles of a Rational Penal Code, 41 Harv. L. Rev. 453, 478

98. A.L.I., Youth Correction Authority Act $\$ 29$ comment (1940). While this comment applies to discharges, the problem of standards is identical to that in the determination of treatment.

99. WARNER \& CABOT, op. cit. supra note 8 , at $174 \mathrm{n}$.

100. Ariz. Code Ann. $\$ 44-2537(2)$ (1939). See A.L.I., Code of Criminal. PROCEDURE $\$ 459$ (1930) (uses the same standard in giving power to reduce an "excessive" sentence).

101. E.g., Idaho Code $\$ 19-2515$ (Cum. Supp. 1951). But compare N.Y. CRIM. CoDE $\$ \S 482,485$ (a) (judge to consider defendant's criminal record, reports of physical or mental examinations, amount of training in "mechanical trade").

102. 18 U.S.C. $\$ 3651$ (Supp. 1952). State statutes are usually similar, e.g., ARIz. Code ANn. §44-2229 (1939). But see Micr. Comp. Laws c. 4, \$771.1 (1948) (court to make recidivist prediction); NEB. Rev. STAT. c. 2, \$\$29-2217, 29-2218 (1.943). Georgia expresses a legislative preference that probation be employed wherever "the circumstances of the case and the public good does not demand or require defendant's incarceration." GA. CODE \$27-2702 (1933) (emphasis added). 
ment dispositions are made "without effective guidance from the law" and "without any norms but those that [courts] may create for themselves." 103

Actually the problem is not whether standards are "precisely expressible." $10 \pm$ Many enumerations of relevant factors have in fact been made in the determination of parole, commutation, appellate review and in foreign legislation. Whenever judges or agencies make treatment dispositions they must decide what information to utilize as relevant to their determination. The legislative vacuum means that judges or treatment agencies are left to do this necessary formulation and application. Thus one judge may refuse to consider any evidence beyond the nature of the offense and the defendant's past criminal record, while another judge under identical circumstances calls for a probation report covering the defendant's whole life history. The difference in the range of treatment factors considered and in the relative weight accorded different factors in this ad hoc judicial discretion is tremendous, reaching the point where in some districts judges give probation in $66 \%$ of their dispositions and in others only $4 \% .{ }^{105}$ It is such disparity in results, implying an equal disparity in the consideration and employment of standards, which calls for reexamination of the legislative role to see how the area now delegated to judicial discretion can be confined and directed.

The legislative problem of formulation of standards relevant to treatment is relatively easy. Aggravating and mitigating factors have been spelled out in many foreign codes ${ }^{106}$ and an interesting example of this legislative individualization was enacted in Iowa 100 years ago. ${ }^{107}$ There are examples of formulation of standards in the decisions of parole boards, pardoning authorities and the few courts which undertake to review sentences. Case by case study of the factors actually expressed and employed is needed to guide legislative action. For the limited purposes of this note a sample of such a study was made by analyzing commutations in New York over a five year period ${ }^{108}$ and sentence reductions in Oklahoma for

103. Wechsler, The Challenge of a Model Penal Code, 65 Harv. L. Rev. 1097, 1102 (1952). The reference is to prosecutors, but it is equally true that sentencing courts and parole agencies "dominate the field without effective guidance from the law." Ibid.

104. See text at note 98 supra.

105. See note 16 supra.

106. E.g., Italy (Articles 61, 62) and U.S.S.R. (Articles 47, 48) in MrCHAEI \& Wechsler, Criminal Law and Its Amainistration 1300, 1301, 1308 (1940); Paimippine Penal Code, arts. 9-11 (1930); Code PENal Suisse ANN. \$\$ 63-64 (Panchaud ed. 1951).

107. IowA CoDE c. 182 , $\$ 3067-3069$ (1851); id., $\$ \$ 4875-4877$ (1860).

108. Commutations for the years 1942-1946, as reported in N.Y. LEGIs. Doc. for the years indicated. Of the 46 commutations, including 7 cases commuted from death to life imprisonment, the following were the factors mentioned and the number of cases in which they appeared: (1) assistance rendered the police, 14; (2) sentence "excessive" under circumstances although mandatory by statute, 13 ; (3) circumstances of the crime, such as emotional strain or slightness of harm done, 9;

(4) good prison record, an apparently supplementary factor, 9; (5) equalization of sentence with accomplice, 4 ; (6) good reputation, 4 ; (7) doubts about prisoner's guilt, 3 ; (8) length of time already served, 3 ; (9) good prior employment record, 1; (10) miscellaneous, 4. 
three years. ${ }^{109}$ There is a similar study of factors used by the Pennsylvania courts in the choice between death and life imprisonment in murder cases. ${ }^{110}$ Presentence investigation reports are available to indicate the kind of material that some judges and probation departments have thought to be relevant, ${ }^{111}$ and there are some data on the factors used in pre-parole investigations ${ }^{112}$ and by the California Adult Authority in setting sentences. ${ }^{113}$ Finally, there have been numerous studies of recidivism, made in an effort to develop a scientific basis for parole and probation prediction. ${ }^{114}$ Standards evolved by psychological testing may offer valid future possibilities here also.

This material reveals both striking similarities and differences as to the relevance and relative importance of different factors. Common to most of the material studied are: the motive for the criminal act, the relative dangerousness of the means by which it was perpetrated; age; the position of the offender and his relationship with the offended; his reputation and social, economic and educational background; and his prior criminal record. The differences are principally in the relative weight accorded these factors, particularly those which involve economic, psychological and sociological considerations. Generally the foreign codes place great stress on the circumstances of the criminal act. This is somewhat less important in the Oklahoma and New York cases studied, where factors not mentioned in the codes, such as aid given to the police or doubts about the guilt of the offender, may be controiling. The non-individualizing factor of equaliza-

109. This study embraced all cases in which sentence reduction was an issue in the years 1939 through 1941, as reported in 65-73 OKLA. CRIM. R. Out of 63 cases, reduction was denied in 25 and granted in 38 . The denials were all in general terms and 15 of the reductions were for no reason more explicit than that the sentence was "excessive" or that there were "mitigating factors." In the remaining cases where the factors were more detailed, prior reputation and criminal record was a factor in 14, with reduction granted because reputation was excellent in 9 and given despite a bad reputation in 5. Equalization of sentence was the motivation in 9 cases, of which 3 were equalization with accomplices and the remainder to bring the sentence within some vague norm or to remove the effects of "passion and prejudice." Other factors : doubts about guilt, 6 ; errors or misconduct prejudicial as to sentence, 6 ; assistance rendered the police, 1 ; good prior employment record, 1.

110. von Moschzisker, supra note 48.

111. See Presentence Investigation Report (Adm. Off. U.S. Cts. 1943).

112. E.g., 4 Atr'y Gen. Survey Release Procedures 145-146 (1939). In 35 jurisdictions, at least at that time, consideration was given only to the criminal record, prison record and recommendation of the trial judge and prosecuting attorney. In only 13 jurisdictions was the data used "fairly adequate" in the range of factor's considered.

113. Philosophy, Principles \& Program of the California Adult AuTHORITY 4-5 (Cal. Dep't Corrections 1945). The CAA sets sentences after the prisoner has served at least six months, and the six factors of "paramount importance" are: (1) nature of the crime; (2) deterrent effect of punishment; (3) equalization of punishment for same offenses under similar circumstances; (4) previous criminal record; (5) prison behavior and attitude (apparently lesser consideration given to this) ; (6) length of time necessary to keep offender under control so he will offend no more.

114. For a review of these see Monachesi, American Studies in the Prediction of Recidivism, 41 J. Crim. L. \& Criminology 268 (1951). 
tion of sentence was found to be important here and in the California Adult Authority.

The recidivist studies, on the other hand, place much more emphasis on economic factors unrelated to the crime or its punishment. Thus the Gluecks found that industrial habits and economic responsibility before the offense bore a very marked relationship to post-parole success or failure ${ }^{115}$ yet in only one New York commutation and one Oklahoma case was this factor given any substantial weight. The Gluecks' work, moreover, indicates that economic and sociological standards may be an accurate guide in deciding whether to grant probation in the first place and whether as it progresses the probationary period is likely to prove successful.116

This is sufficient to indicate the wide range of material which is available for scientific analysis and legislative study. It is no longer necessary to leave the discovery of treatment factors to the uncertain and varied functioning of judicial common sense and "understanding of human nature." 117 Relevant treatment considerations and their relative importance to given treatment objectives are susceptible of legislative ascertainment and formulation. Whether legislation should go beyond this and restrict judges or treatment agencies in their application of these standards raises a more difficult problem. A rigid and perhaps extreme example of such restriction is found in the Philippine Code, which specifies the penalties to be imposed according to the judge's findings of the existence of specified aggravating or mitigating circumstances. ${ }^{118}$ The weight to be accorded the relatively unused non-criminal economic and sociological factors, and the degree to which treatment is to be individualized to the needs of the offender require resolution of conflicts in the basic policy of criminal treatment. The determination of whether or not to utilize probation will in many cases turn upon the relative weight to be accorded retribution, deterrence or individualization. Legislative expression of preference to guide the resolution of such conflicts offers a more satisfactory approach to the problem of criminal treatment than that of leaving each judge free to apply his own philosophy or whim, and the possibility of such legislative weighting is worth serious consideration.

A necessary complement of legislative specification of sentencing standards is a requirement that the sentencing judge make findings of fact as to

115. Glueck \& Glueck, Frve Hundred Criminal Careers 281-282 (1930). The six pre-reformatory factors bearing the highest relationship to post-parole conduct were: industrial habits before sentence, seriousness and frequency of prereformatory crime, arrest for crimes before this one, previous penal experience, economic responsibility before sentence, mental abnormality.

116. Most important factors were industrial habits, family relationships, economic responsibility, type of home and use of leisure. Id., at 284 .

117. Chandler, supra note 1 , at 846.

118. Phintrpine Penal Code, arts. 80-81 (1930). Possible penalties for an offense are divided into degrees, with the maximum to be imposed if the court finds one or more aggravating circumstances, the medium if no finding of aggravating or mitigating circumstances, the minimum if there is one mitigating circumstance, and less than the minimum if more than one mitigating circumstance. 
the existence of those factors in the particular case, and write opinions giving the reasons for his treatment disposition. This suggestion has been vigorously endorsed, ${ }^{110}$ even though it is subject to the same objection noted above-that sentencing is a matter of feeling. ${ }^{120}$ Although such opinions might tend to fall into patterns of routine expression or restrict flexibility by being given undue weight as stare decisis, they are essential. if there is to be adequate judicial review, and they would have value as a start in "rationalizing the sentencing function." 121 Written findings and opinions would serve as a check against haste or transient emotionalism, encourage hearings on relevant factors, stir judicial and public thought on the subject, ${ }^{122}$ and serve as a liaison between the court and the correctional system.

(2) Fair Hearing.-Aside from possible due process requirements, the legislative problem of what kind of hearing is needed in sentencing is revealed by the two extremes which characterize American practice. We have already seen that the common practice places no restrictions on the court and permits the judge to seek and use information from any source without revealing it to the defendant. ${ }^{128}$ At the opposite extreme are the statutes of a few states which not only give the right to a hearing on aggravating and mitigating circumstances but limit a judge's sentencing information to "the testimony of witnesses examined in open court." ${ }^{124}$ Such statutes cripple modern sentencing practices; the presentence probation report used in the federal courts, for example, would be inadmissible.

The practical problem which is posed is not that of admissibility but the utilization of procedural devices to ensure accuracy and allow argument on the relevancy of the disclosed information to the particular circumstances of the case. The presentence probation report in Williams $v$. New York ${ }^{125}$ illustrates this problem. The probation department there concluded that Williams was a "psychopathic liar" whose ideas "revolve around a morbid sexuality," that he was "a full time burglar," "emotionally unstable," "suffers no remorse," and was deemed to be "a menace to society." 126 His criminal

119. WARNER \& CABOT, op. cit. supra note 8 , at 168 , 176; Wyzanski, supra note 5 , at $1292-1293$.

120. Wyzanski, who advocates opinions, reports: "Eminent and wise judges have warned me against [giving reasons for sentences]. Our judgment, they say, is better than our reasons. And it is vain to attempt to explain the exact proportions attributable to our interest in punishment, retribution, reform, deterrence, even vengeance." Ibid. This reasoning raises questions about the validity of opinions that "won't write."

121. WARNER \& CABor, op. cit. supra note 7 , at 168.

122. Ibid.

123. See text at notes $30-34$ supra.

124. E.g., IdaHo CODE $\$ \$ 19-2515,19-2516$ (Cum. Supp. 1951) ; N.D. Rev. CoDE $\$ \$ 29-2619,29-2617$ (1943); ORE. COMP. LAWS ANN. \$\$26-1209, 26-1212 (1940); UTAF REv. STAT. \$105-36-13 (1933). The judge may not consider information obtained in any other way, except for depositions in limited situations where a witness cannot be present.

125. 337 U.S. 241 (1949). See discussion in the text at notes 86-87 supra.

126. Transcript of Record, pp. 16-18, Williams $\nabla$. New York, supra. 
record, confined to a charge of theft when he was 11 years old and a conviction as a wayward minor, did not support such generalizations. The conclusions of the probation department were apparently based upon (1) stolen goods found in his room, (2) identification of Williams by a woman whose apartment he allegedly burglarized and a seven year old girl he had allegedly raped, (3) allegations that he had committed "about 30 burglaries," and (4) "there was information" that he had acted as a "pimp" and had been observed taking indecent photographs of young children. ${ }^{127}$ Aside from the truth or falsity of these statements or their adequacy as a basis for a death sentence, in this case life or death turned upon conclusions drawn by probation officers from hearsay and from unproven allegations. ${ }^{128}$ Such information is highly relevant to the question of sentence, but its accuracy depends upon the ability and fairness of the probation officer, who must weigh evidence, judge the credibility of the informants and be zealous in closely examining them and probing for what Wigmore calls "the possible (and usual) remainder." 129 Where probation officers are "experienced professional men, habitually inquiring day after day into the same limited class of facts," the necessary skills may often be applied; ${ }^{130}$ but at best this method of ascertaining facts has serious deficiencies because it relies for cross-interrogation and cross-investigation upon one "who has neither the strong interest nor the full knowledge that are required," 131 and which usually only the defendant can provide.

The hearing on such presentence information would present difficult problems because of the hearsay character of probation reports. If the informants upon whose statements the reports are based must all be produced to give their testimony before the defendant and be subject to crossexamination, the procedure would threaten to "endlessly delay criminal administration in a retrial of collateral issues." 132 Forcing all presentence information through the needle's eye of trial evidentiary procedure would mean that "most of the information now relied upon by judges to guide them in the intelligent imposition of sentence would be unavailable." 133 Part of the solution of this problem may be found by drawing an analogy to British practice. There a police witness, in a hearing on sentence, may

127. Ibid.

128. Compare Cox v. State, 64 A.2d 732, 738 (Md. 1949), where a presentence medical report with sweeping generalizations called the defendant "a psychopathic personality who has shown little feeling for the property rights of others and takes the easiest way out when he is confronted with the need for money" and who "looks and talks more intelligent than he really is."

129. 5 Wigmore, Evidence $\$ 1368$ (3d ed. 1940). For a discussion of the evidentiary problems involved in social case work investigations see 1 Id. $\$ 4(f)$.

130. $1 \mathrm{Id}$. $\$ 4(\mathrm{~b})$. Note that many of these reports present a double hearsay problem. The probation officer who prepares the report and draws the inferences may not be the one who has talked with the informant, thus causing an additional possibility of error.

131. 5 Id. $\$ 1368$ n.1.

132. Williams v. New York, 337 U.S. 241, 250 (1949).

133. Ibid. 
not "make allegations which are incapable of proof, and which he has reason to think will be denied by the prisoner," 134 and if the prisoner denies any statements made during sentencing, the court "may require legal proof of it, or he may ignore it . . ."135 Presentence information to be considered by the court, such as a criminal record, a probation investigation report, or character or employment evidence on behalf of the defendant, should be submitted in advance to the opposing party. If objection were made as to the accuracy of any information, there could be an informal presentence conference to decide on whether the controverted facts should be ignored or what kind of proof might be required. ${ }^{136}$ Knowledge that presentence reports would be subjected to such scrutiny and possible challenge would lead to greater care and accuracy in their preparation. The danger of abuse and delaying tactics by defendants would be minimized through the use of the conference suggested above and by the natural desire of defense counsel not to antagonize the sentencing court.

One advantage of present sentencing practice which would be lost under such a hearing procedure is the anonymity afforded informants when the presentence report is not disclosed to the defendant. Unquestionably the confidential nature of probation investigations encourages fuller disclosure of information than would obtain if informants knew that their identity would be revealed to the defendant and that they might be called to the stand and subjected to cross-examination. ${ }^{137}$ Public policy favors such full information, for it is a prerequisite to intelligent individualization of treatment. But even from this viewpoint the advantage of anonymity must be questioned. Anonymity also encourages misinformation and removes an incentive for accuracy and thoroughness by those obtaining the information. Permitting anonymity under these circumstances is an exception to the abhorrence of secret testimony of unknown witnesses which is reflected in our judicial system, ${ }^{138}$ which shows an awareness that the

134. Rex v. Van Pelz, 1 All E.R. 36, 38 (Ct. Crim. App. 1943).

135. Rex v. Campbell, 6 Crim. App. Rep. 131, 132 (1911).

136. Such proof need not necessarily be "legal" proof, and confrontation might not be required. IowA CoDE $\$ 4877$ (1860) had an interesting provision outlining the procedure whereby aggravating and mitigating circumstances could be "proved" either by the examination of witnesses in open court or by their affidavits, as the court may deem most conclusive to justice in each particular case; but the opposite party must, in all cases, have an opportunity of cross-examining the witnesses, or of producing counter-affidavits, or evidence, if he require it."

Whether or not an informant of disputed facts must be produced for crossexamination or whether affidavits would suffice could be left to the discretion of the court, and should depend on the facts.

137. See Note, Right of Criminal Offenders to Challenge Reports Used in Determining Sentence, 49 CoL. L. REv. 567 (1949).

138. E.g., United States v. Cotton Valley Operators Committee, 9 F.R.D. 719 (W.D. La. 1949) (anti-trust prosecution dismissed when government refused to comply with court order to produce F. B. I. reports, and court rejected government's compromise proposal to produce only "an abstract of factual information contained in" the reports). See United States ex rel. Touhy v. Ragen, 340 U.S. 462 (1951); United States v. Nugent, 21 U.S.L. Week 2230 (2d Cir. Nov. 10, 1952). 
products of such investigations are highly susceptible of abuse and error. Where there have been other exceptions, the overriding policy reason has been national security. ${ }^{139}$ The compromise possibility of giving the defendant an abstract of information contained in the probation report without revealing the identity of the informants would be generally unsatisfactory. If the abstracted information were explicit, the defendant would probably be able to determine the identity of the informant anyway and anonymity would be lost. If the information were sufficiently indefinite to conceal the informant's identity, it would place on the defendant the often insuperable burden of rebutting vague generalities, thus depriving him of real notice of the evidence against him. Particularly where the crucial information turns on the reputation of the defendant or on alleged prior criminality based on unproven charges or supposed confessions, as was the case in Williams $v$. New York, ${ }^{140}$ the chance of prejudicial error is great unless there is full notice of the nature and source of the allegations. To the extent that the reason for permitting non-disclosure of sentencing information is the doctrinal one that a convicted criminal has no "rights" as to sentence, it is being undermined by the due process development in sentencing procedure. With national security considerations absent, there is no sound reason for making this exception in a procedure where in fact the defendant's life or liberty turns on the disposition which is made. The solution is to obtain as full information as is possible without sacrifice of fairness and accuracy. Free admissibility so that sentencing information can be received by the judge without evidentiary restrictions which are in force before conviction, coupled with full notice to the defendant so there can be an opportunity for rebuttal, offers a workable compromise.

There is no doubt that such sentencing hearings would impose a substantial new burden upon already overloaded courts. But if such hearings are necessary to achieve more rational and uniform sentencing practices and meet due process requirements, then this objection is merely part of the broader complaint that present facilities for the administration of the criminal law are inadequate to the task.

The necessity of providing a hearing in the trial court would not be obviated by transfer of the sentence-fixing function to a dispositions tribunal.141 Since the most important single treatment decision-probation-is made by the trial court, the necessary information must be available at that time. Nor is there any indication that the hearing problem is anything but aggravated when sentence-fixing is done by administrative tribunals. Advocates of dispositions tribunals have realized that procedural

139. See the recent regulations granting administrative review for denial of a passport, under which the person affected shall be given notice of the reasons for refusal "as specifically as in the judgment of the Department of State security considerations permit." 17 FED. REG. 8013 (1952).

140. See text at notes 125-126 supra.

141. This has been done in California, see note 113 supra. 
protection of the offender raises "the greatest technical difficulties," 142 and available information on the operations of administrative sentence-fixing agencies indicates the seriousness of the problem. The volume of cases handled can only mean that the hearings accorded are of the most summary character. ${ }^{143}$ The reliability of the fact-finding upon which decisions are made has been challenged. ${ }^{144}$ Thus the whole problem of an adequate procedural system in trial court sentencing is paralleled by the even greater absence of minimum safeguards in administrative sentence-fixing.

(3) Appellate Review.-The experience of the Oklahoma and English Courts of Criminal Appeals indicates what can and what can not be expected from judicial review of sentencing. The English court has the power to review a sentence on appeal, to hear fresh evidence relative thereto, and to pass such other sentence, more or less severe, as it sees fit. ${ }^{145}$ It will also scrutinize the presentence information given to the judge, and if the Court of Criminal Appeals thinks an "improper statement" influenced the sentencing court, sentence will be reduced.146

The Oklahoma court exercises similar control over both the sentence and the procedure utilized in reaching it, and has modified sentences because of "excessiveness," because it has given added weight to mitigating factors, because of nonreversible errors which were prejudicial as to sentence, or because of misconduct by the prosecuting attorney. ${ }^{147}$ Thus the grossly disproportionate sentence can be corrected, sentencing procedure supervised, and a certain measure of uniformity introduced.

An illustration of the practical utility of judicial review when combined with standards and trial court opinions is the Duker case in Maryland, where the defendant pleaded guilty to murder and was sentenced to death. Judge Ulman, although finding that Duker was a "psychopathic personality" with reduced mental and moral responsibility and that to hang him was

142. Glueck, supra note 97, at 477. He suggests hearings and "safeguarding of individual rights by permitting the defendant to have counsel and witnesses [of fact and opinion], and to examine psychiatric and social reports filed with the tribunal, while at the same time avoiding a technical, litigious procedure, hidebound by strict rules of evidence. . . ." Id., at $479 \mathrm{n}$. Similar suggestions have been made by Orfiemd, Crminal Appeals in America 120 (1939) and Warner \& Cabot, op. cit. supra note 7 , at $174 \mathrm{n}$.

143. In 1948 the three member California Adult Authority was holding an average of 527 hearings with 479 "personal appearances" and deciding hundreds of other actions per month. Final Report, Special Crime Study Commission on Adult Corrections \& Retease Procedures 38 (Cal. Adult Auth. 1949). In Washington the board holds about 175 hearings in 5-8 days. 8 BIEN. REP. BD. PRISON TrRMS \& Paroles 14 (Wash. 1951). There were 6,692 inmate appearances before the three member New York Board of Parole in 1946. 17 Rep. Div. of Parole in 12 N.Y. LEGIS. Doc. 33 (1947). The five-member U.S. Board of Parole decided an average of 9,000 cases a year in 1947-1951. FEDERAL PrIsons 58 (U.S. Dep't Jus. 1952). None of these agencies permitted the prisoner to have counsel or witnesses at the hearings.

144. Monachesi, supro note 114 , at 286.

145. 7 Edw. VII, $\$ 3(c), 4(3)$ (1907).

146. E.g., Rex v. Everitt, 8 Crim. App. Rep. 156 (1913); Rex v. Burton, 18 Crim. App. Rep. 89 (1941).

147. See note 109 supra. 
"a confession of social and legal failure," nonetheless imposed the death sentence because Duker would represent "a serious threat against the lives of the other prisoners and of the guards" if sent to the penitentiary. The Maryland Court of Appeals refused to modify the sentence under its doctrine of non-reviewability, ${ }^{148}$ but the sentence was commuted by the Governor who found, after a further hearing, that there was "no substantial evidence" to justify the trial judge's prediction of Duker's penitentiary conduct. ${ }^{149}$ Executive clemency was here used to perform a function for which it is not fitted and which at best it can fulfill only occasionally, but which could be handled by judicial review.

The English decisions have been criticized because the Court of Criminal Appeals has apparently been guided by rather narrow legal considerations, and the guiding principles evolved "are disappointing in not being sufficiently grounded in psychologic and sociologic considerations." 150 This would appear to be expecting too much of judicial review. Standards to guide sentencing must be determined on a legislative level or, upon legislative abdication, by the trial courts. Appellate review can do little more than correct serious abuse of those standards and supervise procedure. But those objectives are nonetheless important even when thus limited.

\section{ConcLusion}

Changes in sentencing procedure away from non-reviewable judicial discretion may be indicated by the implications of Townsend $v$. Burke that due process requires some type of hearing on sentence determination. Such a development would recognize that vital interests of both the defendant and society are at stake in treatment dispositions and that increased procedural protections are essential to guard against arbitrariness and to keep pace with the increasing emphasis upon individualization in criminal treatment. Decision as to the kind of hearing to be provided presents difficulties in adjusting (1) the interest of society in getting full information about the defendant and (2) the interest of the defendant in having an opportunity for notice and rebuttal to ensure accuracy. It is possible that such a balance can be achieved without substantial sacrifice of necessary procedural flexability in sentencing. Provision for adequate hearing, more precise legislative formulation of standards to be applied, and written opinions and appellate review would reduce the illogical disparity and abuse which characterize much sentencing at present, and would stimulate thought and experimentation in the efficacy of varied treatment techniques.

148. Duker v. State, 162 Md. 546, 160 At1. 279 (1932).

149. Ulacan, A Judge Takes the Stand 211-220, 273-285 (1933).

150. Glueck, Crime and Justice 326 n.27 (1936). 